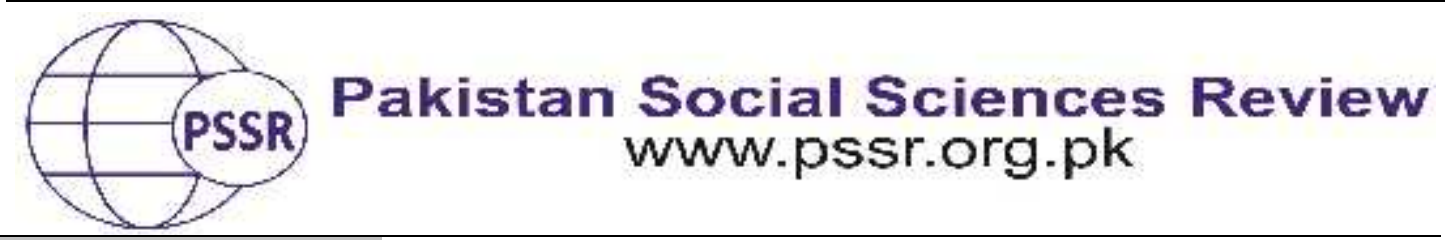

RESEARCH PAPER

\title{
Pakistan Tehreek-Insaf's Strategy for Polls: A Comparative Study of Candidates in 2013 and 2018 General Elections of Pakistan
}

\author{
Syed Karim Haider ${ }^{1}$ Imran Khan ${ }^{2}$
}

1. Lecturer, Pakistan Study Centre, University of the Punjab, Lahore, Punjab, Pakistan

2. Lecturer, Government Post Graduate College Hafizabad, Punjab Pakistan

\begin{tabular}{|c|c|}
\hline PAPER INFO & ABS \\
\hline Recei & Pakistan Tehreek Insaf (PTI) emerged on the political scene of \\
\hline 3, 2019 & Pakistan as the third political \\
\hline Acce & and political trend setter. The \\
\hline Jun & a laun \\
\hline Onl & after these elections and afte \\
\hline June & \\
\hline Key & calculation of \\
\hline $\begin{array}{l}\text { Can } \\
\text { Gen }\end{array}$ & 2013 and 2018. This study provides a \\
\hline & rom \\
\hline Elec & Is. This study will \\
\hline & help to understand the draw $\mathrm{b}$ \\
\hline & PKe \\
\hline & d Center and second political force in Sindh but failed \\
\hline Corresponding & \\
\hline Authc & \\
\hline $\begin{array}{l}\text { haider.psc@pu.e } \\
\text { du.pk }\end{array}$ & $\begin{array}{l}18 \text { elections that is visible in the } \\
13 \text { and } 2018 \text { elections contesting }\end{array}$ \\
\hline
\end{tabular}

\section{Introduction}

Any political party or political alliance in Pakistan needs to win at least 50 percent of the general seats of the National Assembly in elections to form a government at national level. Same is the situation for the political party if it desires to form government at the provincial level. The second important thing is suitability of the candidates, contesting on the party tickets. But in the May 11, 2013 elections, PTI was almost non-existent in the 50 percent of the National Assembly constituencies. The security deposits of the PTI's candidates were confiscated in the 93 constituencies and PTI remained fail to post any candidate in 40 constituencies. It meant that PTI was almost non-existent in precisely 133 constituencies out of 272 total constituencies of the National assembly. PTI's selection committees and its 
leadership were responsible for the said condition and PTI must have to revisit its strategy to avoid the in 2018 elections. Looking at the number of candidates posted by PTI in 2018 it become visible that PTI did not change the quantity of Candidates but quality of candidates with exception to Baluchistan where both quality and quantity were not changed (PILDAT, August 2018).

PTI leadership of KPK chapter performed well in the 2013 election and Imran khan trusted the provincial leadership in selection of the Candidates and outcome remained positive in the Center and Punjab provincial matters Party's Central leadership played a role in nomination of Candidates and outcome was positive. In case of Sindh and Baluchistan no serious work was done and outcome in urban Sindh became satisfactory whereas in rural Sindh and Baluchistan the neglecting policy of PTI result brought positive change in comparison to 2013 elections. This study will present the data to analyze the performance of the PTI by making the comparison of the quantity of the Candidates contesting the elections of 2013 and 2018 on PTI's tickets and it will critically produce the facts about the strategy of PTI in posting the candidates to contest the elections at national and provincial level (EOM, The 25 July General Elections in Pakistan, 2018).

\section{Literature Review}

Gallup Pakistan issued a report on the general elections of Pakistan after the elections and explains the election system of Pakistan. Gilani Research Foundation and Gallup Pakistan have working relationships to find out facts and figures to understand electoral politics in Pakistan and to explain the multipart behavioral and social ties that run below. This particular report on the general elections of 2013 in Pakistan offers an understanding of general elections in expressions of facts and figures. This Gallup report is part of a special work that aims to deliver the readers stimulating findings from the electoral database of Gallup Pakistan. The database of the elections of 2013 had been consolidated from the data of ECP (Elections Commission of Pakistan) by the Data Analytics team of Gallup Pakistan and analyzed by the experts. (PILDAT, The First 10 General Elections of Pakistan, August 2018)

Pakistan was once again prepared in 2018 for a free, fair general elections and the election commission of Pakistan Professionally managed the 11th General Election, despite the fact that many political parties of Pakistan and individuals questioned the impartiality of the elections and doubted the management of 2018 General Elections that was held in Pakistan on July 25.Pakistan Institute of Legislative, Development And Transparency (PILDAT) as private and impartial NGO issued its report about the general election of 2018 in Pakistan and explained that the hope and expectation of people of Pakistan for a free, fair election was not unprejudiced due to the outstanding administrative preparations by the (ECP) Election Commission of Pakistan but also due to the key legal reforms that been introduced in Pakistan since after the General Elections of 2013.PILDAT As an independent, political think tank has sustained to methodically analyze the electoral 
developments leading up to General Elections of Pakistan held in 2002, 2008, 2013 and 2018. PILDAT has also carried out free and fair, methodical and objective assessments of the excellence of Pakistan's General Elections post their conduct. This report is calculation of the value of 2018's General Election carries the outcomes of the post-election calculations carried out by PILDAT and eminent experts who are members of discussion Groups of PILDAT. (PILDAT, August 2018)

The European Union had deployed an Election Observation Mission to analyze the 2018' general elections going to be held on 25 July and the mission was also greeted by the Election Commission of Pakistan (ECP). The EOM of EU was present in Pakistan to observe the elections for two months from 24 June 2018 to 23 August 2018. The EOM directives were to observe all characteristics of the electoral development and assess the scope to which the polls complied with worldwide commitments for general elections, as well as with domestic legislation. This report on the 2018's general elections comprise the findings of the EU EOM that is autonomous from European Union institutions, and consequently the report was not an authorized version of the European Union. (EOM, The 25 July General Elections in Pakistan, 2018)

\section{Hypothesis}

Pakistan Tehreek Insaf won the 2018 election by bringing change in its strategy of posting candidates but the focus of change was limited to Punjab that deprived it to secure a simple majority in the National Assembly and ultimately it had to form a coalition government.

\section{Material and Methods}

The secondary sources of data are used in this study and descriptive model of research is used to describe the facts and figures of elections of 2013 and 2018. The comparative model of the research methodology is used to compare the figures regarding the 2013 and 2018 elections in Pakistan. This research paper is based on the produced data that is analyzed to compare the two recent elections in Pakistan in the context of candidates filed by Pakistan Tehreek Insaf is chosen as political party for comparison because it emerged as third federation level party on the political scene of the country and formed government in Pakistan. The changes in the percentage of the winning and losing candidates are used as an indicator to check the importance of selection of candidates in election, help in this regard is taken from the books, articles, newspapers and online martial in this study.

\section{Results and Discussion}

Table 1

Party Candidates in 2013 Elections

\begin{tabular}{llllll}
\hline Election 2013 & Candidates & Won & Votes & \% of Vote & Wining \% \\
\hline National Assembly & 233 & 28 & 7747383 & 17 & 12 \\
\hline
\end{tabular}




\begin{tabular}{llllll}
\hline Punjab Assembly & 285 & 20 & 4960044 & 18 & 07 \\
\hline Sindh Assembly & 86 & 3 & 609128 & 6 & 03 \\
\hline $\begin{array}{l}\text { Khyber } \\
\begin{array}{l}\text { Pakhtunkhwa } \\
\text { Assembly }\end{array}\end{array}$ & 98 & 35 & 1040007 & 19 & 36 \\
\hline $\begin{array}{l}\text { Baluchistan } \\
\text { Assembly }\end{array}$ & 25 & 0 & 23929 & 2 & 0 \\
\hline Total & 727 & 86 & 14380491 & & 12 \\
\hline
\end{tabular}

If the second position holders are considered right choice, there were 286 candidates who retained the trust of the party leadership and scored well in the election as 200 candidates remained second in the election's race of 2013. (DESK, 2013)

441 tickets of the PTI were given to the incompetent candidates or in 441 constituencies people not consider the PTI as alternate to their existence political affiliation. The selection committee of PTI from Khyber Pakhtunkhwa remained more precise in choosing the rightful candidates or PTI as political party played major role in winning the seats as the winning ratio on Party Tickets is 36 percent in KPK. 98 candidates in KPK run with the PTI symbol of Bat, for the 99 general seats of the KPK assembly. 35 out of 98 secured first position whereas 6 remained runners up. It is indicating that only 41 candidates were rightly chosen to assign the tickets in Khyber Pakhtunkhwa by PTI and 57 candidates remained fail to prove themselves as right choice for the elections in 2013 and satisfactory graph touched the $42 \%$ ratio. Pakistan TehreekInsaf issued tickets for 727 candidates in the elections of 2013 and 86 out of these candidates could secure their position and retained the trust of party leadership.

The second-best selection of the party candidates remains in center for the seats of National Assembly because PTI nominated 233 candidates for the 271 general seats and it could secure 28 seats in the nationals Assembly 76 of its candidates remain second and the satisfactory candidature choice of PTI in the National assembly Seats becomes 104 candidates. The winning percentage on party tickets became 12 percent in the center for PTI. If the second position holders in polls include as satisfactory choice as the satisfactory graph reached at the 47 percent. 127 candidates failed to satisfy the party leadership about their selection for tickets. Party leadership of PTI sitting in the center was not vigilant but also less than the Khyber Pakhtunkhwa selection team to assign tickets to the right candidates for the constituencies. (KPK, 2018)

Third position in the right decision making for the selection of the right candidate for polls of 2013 was secured by the party leadership of Punjab in which the party remained successful to nominate 285 candidates for the 297 general seats of the Punjab assembly. 20 candidates out of 285 could secure first position and 93 candidates remained runner up in the polls, so the winning percentage in Punjab remained 7 percent if the runner up included in the right choice the percentage reached 40. (Officials, 2018) 
Looking at the position of Sindh 86 party tickets were given to candidates by PTI for the 130 general seats of Sindh Assembly. Party failed to cover all the constituencies due lack of access in rural Sindh and seat adjustment with other parties. Only 3 candidates secured first position in Sindh and 24 secured second position and winning percentage in Sindh remained at fourth position with 3 percent. If the second position holders are included as the right choice for party tickets then the percentage rises up to 31 percent. 61 candidates in Sindh remain unable to satisfy the party leadership about their choice to award party tickets. The leadership of Sindh chapter of PTI remained unable to select the right candidates to contest the election on party ticket. (Officials, Final Signature List Sindh, 2018)

The worst situation for the PTI in candidate selection remained in Baluchistan province where only 25 candidates ran for election on PTI tickets and 26 seats left vacant and without candidates in the Baluchistan assembly. No candidates out of 38 could secure first position in Baluchistan and the winning percentage was zero in 2013 elections. If the second position holders in the Baluchistan assembly are considered as the right choice then only one candidate could be included in the list as only one candidate on the PTI ticket remained second and the percentage becomes 4 percent in this 2013 election. 34 candidates failed in Baluchistan to justify the choice of their party leadership. (Officials, Baluchistan Final Signature List, 2018)

So the selection committee of PTI of Khyber Pakhtunkhwa comes first by filing maximum candidates for all constituencies of the KPK assembly and achieving 36 percent winning candidature. The selection committee of PTI in center comes second by achieving 12 percent winning candidature. So the selection committee of PTI of Punjab chapter comes third by achieving 7 percent winning candidature. The selection committee of PTI of Sindh chapter came forth by achieving only 3 percent winning candidature and the selection committee of PTI of Baluchistan chapter performed worse as it remained unable to award tickets to a single winning candidate from Baluchistan. (Defence, 2013)

Table 2

Party Candidates for 2018 Elections

\begin{tabular}{cccccc}
\hline Election 2018 & Candidates & Won & Votes & \% of Vote & Wining $\%$ \\
\hline National Assembly & 245 & 116 & 1695905 & 32 & 47 \\
\hline Punjab Assembly & 284 & 121 & 11157945 & 34 & 43 \\
\hline $\begin{array}{c}\text { Sindh Assembly } \\
\text { Khyber Pakhtunkhwa } \\
\text { Assembly }\end{array}$ & 97 & 23 & 145113 & 14 & 23 \\
\hline Balochistan Assembly & 96 & 65 & 2133112 & 32 & 68 \\
\hline Total & 38 & 5 & 109757 & 6 & 13 \\
\hline
\end{tabular}

Pakistan TehreekInsaf issued tickets for 760 candidates in the elections of 2018 and 330 out of these candidates could secure their position and retained the trust of party leadership. (Pakistan, 2018) 
If the second position holders are considered the right choice as there are 610 candidates who retained the trust of the party leadership and scored well in the election as 280 candidates remained second in the polls race of 2018. (Alvi, June 24, 2018)

160 tickets of the PTI were given to the incompetent candidates or on 160 constituencies people not consider the PTI as alternate to their existence political affiliation. The PTI leadership from Khyber Pakhtunkhwa chapter remained more accurate in choosing the rightful candidates or PTI as political party played major role in whining the seats as the winning ratio on Party Tickets is 68 percent in KPK. 96 candidates in KPK run with the PTI symbol of Bat, for the 96 general seats of the KPK assembly as elections on one seat was postponed. (EOM, The 25 July General Elections in Pakistan, 2018)

65 out of 96 secured first position whereas 17 remained second in the race to win the elections. It is indicating that the 82 candidates were rightly chosen to assign the tickets in Khyber Pakhtunkhwa by PTI and only 14 candidates remained to prove themselves as the right choice for the elections in 2018 and the satisfactory graph touched the 85 percent ratio. The second-best selection of the party candidates remains in center for the seats of National Assembly because PTI nominated 245 candidates for the 271 general seats and it could secure 116 seats in the nationals Assembly 89 of its candidates remain second and the satisfactory candidature choice of PTI in the National assembly Seats becomes 204. The winning percentage on party tickets became 47 percent in the center for PTI. If the second position holders in polls include as satisfactory choice as the satisfactory graph reached at the 83 percent. Only 41 candidates failed to satisfy the party leadership about their selection for tickets. Party leadership of PTI sitting in the center was vigilant but less than to the Khyber Pakhtunkhwa for the selection of the right candidate for the constituencies. Third position in the right decision making for the selection of the right candidate for polls of 2018 is secured by the party leadership of Punjab in which party after seat adjustment with the other parties remained successful to nominate 284 candidates for the 297 general seats of the Punjab assembly. 121 candidates out of 284 could secure first position and 140 candidates remain runner up in the polls, so the winning percentage in the Punjab remain 34 percent that is $3^{\text {rd }}$ in line after KPK and Center but the accuracy in Punjab became 91 percent if the second position holder included as best choice of the candidates as 261 out 284 candidates in Punjab performed satisfactorily.

Looking at the position of Sindh 97 party tickets were given to candidates by PTI for the 130 general seats of Sindh Assembly. Party failed to cover all the constituencies due lack of access in rural Sindh and seat adjustment with other parties. 23 candidates secured first position in Sindh and 32 secured second position and winning percentage in Sindh remained at fourth position with 23 percent. If the second position holders are included as the right choice for party tickets then the percentage rises up to 57 percent. 42 candidates in Sindh remain unable to satisfy the 
party leadership about their choice to award party tickets. The leadership of Sindh chapter of PTI remained unable to select the right candidates to contest the election of party ticket. (Pakistan, PRESS RELEASES, 2021)

The worst situation for the PTI in candidate selection remained in Baluchistan province where only 38 candidates ran for election on PTI tickets and 13 seats left vacant and without candidates in the Baluchistan assembly. 5 candidates out of 38 could secure first position in the Baluchistan and the winning percentage reached only 13 percent. If the second position holders in the Baluchistan assembly are considered as the right choice then only 2 more candidates could be included in the list as 2 candidates on the PTI remained second in the elections and including them the total of right choice becomes 7 out of 38 and the percentage becomes 18 percent. 31 candidates remained failed in Baluchistan to justify the choice of PTI leadership of Baluchistan chapter. So, the selection committee of PTI of Khyber Pakhtunkhwa chapter comes first by filing maximum candidates for all constituencies of the KPK assembly and achieving 68 percent winning candidature.

The selection committee of PTI in center comes second by achieving 47 percent winning candidature. So, the selection committee of PTI of Punjab chapter comes third by achieving 43 percent winning candidature. The selection committee of PTI of Sindh chapter comes fourth by achieving 32 percent winning candidature and selection committee of PTI of Baluchistan chapter performed worse by achieving only 13 percent winning candidature. Consider the runner up candidates as the right choice at the party end the position of the selection committees is changed and Punjab comes first by achieving 91 percent and KPK chapter comes after it with 85 percent and central selection committee comes third with 83 percent. Whereas applying the same formula in Sindh chapter the position remained same at fourth as right choice of candidate rose up to 57 percent and Baluchistan with 18 percent again became the worst performing province for PTI in 2018 elections (Pakistan, PRESS RELEASES, 2021).

\section{Comparing the 2013-2018 Elections Candidates of PTI}

\section{Candidates for the National Assembly}

In the 2013 elections, the second best selection of the party candidates remains in center for the seats of National Assembly because PTI nominated 233 candidates for the 271 general seats but only 28 could win seats in the national Assembly in 2018 elections PTI nominated 245 candidates for the 271 general seats and it could secure 116 seats in the nationals Assembly. (Officials, Baluchistan Final Signature List, 2018)

In 2013 elections 76 candidates of PTI remained second and the satisfactory candidate choice of PTI in the National assembly Seats becomes 104 candidates whereas in 2018 election the 89 candidates of PTI remain second and satisfactory 
candidature choice of PTI in the National assembly Seats becomes 204 considering runners up a right choice. (News, 25 June 2018)

Looking at the winning percentage on party tickets it was 12 percent in the 2013 elections and 47 percent in 2018 in the center for PTI whereas in 2018 elections. In 2013 elections, 129 candidates failed to satisfy the party leadership about their selection for tickets whereas in 2018 elections only 41 candidates remained failed to satisfy the Party leadership of PTI. So, in the 2018 elections, 88 more candidates justified their selection more than the 2013 election (News , 2013).

\section{KPK Assembly}

In 2013 and 2018 elections the PTI leadership from Khyber Pakhtunkhwa chapter remained more exact in choosing the rightful candidates as the winning ratio on Party Tickets in 2013 was 36 percent that rose to 68 percent in 2018 elections. (Officials, Baluchistan Final Signature List, 2018)

In 201398 candidates in KPK ran on the PTI tickets and 35 candidates could win whereas in 2018, 96 candidates in KPK ran on the PTI tickets and 65 candidates could win on 99 general seats of the KPK assembly. PTI contested all seats in 2013 and 2018 as elections on the remaining general seats were postponed. (News G. , PTI issues list of election candidates, 2018)

65 out of 96 secured first position whereas 17 remained second in the race to win the elections. It is indicating that the 82 candidates were rightly chosen to assign the tickets in Khyber Pakhtunkhwa by PTI and only 14 candidates remained to prove themselves as the right choice for the elections in 2018 and the satisfactory graph touched the 85 percent ratio. (News, 2013)

\section{Punjab Assembly}

PTI Punjab chapter secured third position in the right decision making for the selection of the right candidate for polls. (News, 25 June 2018)

In the 2013 election PTI remained successful to nominate 285 candidates for the 297 general seats of the Punjab assembly whereas in 2018 elections PTI remained successful to nominate 284 candidates for the 297 general seats of the Punjab assembly. Only one less the 2013 elections and it was due seat adjustment with the ally party of Punjab.(News, 25 June 2018)

In the 2013 elections the 20 PTI candidates out of 285 could secure first position whereas in 2018 elections 121 candidates secured victory on PTI tickets means 101 more seats in 2018 election in Punjab assembly. In the 2013 election 93 candidates of PTI remained runner up, whereas 140 candidates remained runner up in the 2018 polls. So the winning percentage of candidates on PTI tickets in Punjab in 
2013 remains 7 percent and 34 percent in 2018 that is 27 percent better (News , 2013).

\section{Sindh Assembly}

In 2013 elections PTI in Sindh awarded 86 party tickets and in 2018 election number was 97, meaning 11 more candidates in comparison to 2013 elections for the 130 general seats of Sindh Assembly (Officials, Baluchistan Final Signature List, 2018).

Party failed to cover all the constituencies in both elections due lack of access in rural Sindh in 2013 elections and in 2018 election due to seat adjustment with other parties (News, 25 June 2018).

Only 3 candidates' secured first position in Sindh in 2013 elections and 23 in the 2018 elections means 20 more seats in the Sindh Assembly in 2018 elections. (News, 25 June 2018)

In the 2013 election 24 candidates of PTI secured second position and 32 secured second positions in 2018 elections. In 2013 elections winning percentage in Sindh for PTI Candidates remained at 3 percent whereas in 2018 elections it was 23 percent. In 2013 elections 61 candidates in the Sindh remain fail to satisfy the party leadership about their choice to award party ticket in 2018 election 42 candidates in the Sindh remain fail to satisfy the party leadership about their choice to award party ticket if the second position holders in elections are included as just choice of party leadership.(News D. , 2013)

\section{Baluchistan Assembly}

In 2013 elections PTI nominated 25 candidates to run for election on PTI tickets and 26 seats left vacant and without candidates in the Baluchistan assembly whereas in 2018 elections 38 candidates ran for polls from PTI platform. It means 13 more candidates in comparison to 2013 elections (Officials, Baluchistan Final Signature List, 2018).

In the 2013 election no candidates out of 38 could win in Baluchistan whereas 5 candidates won the election of 2018 in Baluchistan. The winning percentage was zero in the 2013 elections whereas in 2018 it remains at 13 percent.

If the second position holders in the Baluchistan assembly are considered in the 2013 election as the right choice then only one candidate could be included in the list whereas in 2018 two candidates remained second in the elections. In the 2013 elections 34 candidates remained failed in Baluchistan to justify the choice of their party leadership, the figure remained 31 in the 2018 election including the runners up in the right choice to candidate. 


\section{Conclusion}

In the general elections of 2013 Pakistan TehreekInsaf issued tickets for 727 party tickets whereas in 2018 elections it issued 760 tickets to the candidates of the National and Provincial assemblies (EOM, The 25 July General Elections in Pakistan, 2018).

So PTI issued 33 more tickets to the candidates in compare to the 2013 elections or candidate preferred PTI tickets to contest the election. Only 86 candidates in 2013 election could win elections in compare to 330 in the 2018 elections that was great achievement for PTI after five years of protest and political activities and link with the people. If the second position holders are considered right choice because there were 200 runners up candidates in the 2013 elections whereas the number was 280 candidates remained second in the polls race of 2018 . So, the numbers of runners up candidates also increased in the 2018 elections as 80 more candidates join the list of 200 candidates on 2013 elections.

In the 2013 elections 441 tickets of the PTI were given to the incompetent candidates and in 2018 this number restricted to 170. In 2013 the loser on PTI tickets were 641 in comparison to 2018 when 430 candidates lost the elections contesting on the PTI tickets, so 211 candidates secured more seats in 2018 in comparison to 2013. (News , 2013). 


\section{Reference}

Alvi, M. (2018, June 24). PTI list of candidates to come on 25th. Islamabad: Pakistan.

Defence, P. (2013). PTI Ticket holders. Islamabad: Pakistan Defence 2013.

DESK, W. (2013, April 22). Pakistans Today. Imran Khan surprises all by putting up 767 candidates.

EOM, E. (2018). The 25 July General Elections in Pakistan. Islamabad: EU EOM 2018.

EOM, E. (2018, July). The 25 July General Elections in Pakistan. Islamabad.

KPK, P. A. (2018). Member's Directory. KPK: KPK 2018.

News, D. (2013). The election score. Islamabad: 16 May, 2013.

News, G. (2018). PTI issues list of election candidates. Islamabad: July 28, 2018.

News, G. (2018, June 25). PTI issues list of election candidates. Islamabad: GEO News.

Officials, P. (2018). Baluchistan Final Signature List. Quetta: PTI Officials.

Officials, P. (2018). Final Signature List PUNJAB. Lahore: PTI 2018.

Officials, P. (2018). Final Signature List Sindh. Karachi: PTI Officials 2018.

Pakistan, E. C. (2018). Delimitation 2018 Map Kpk Final. Islamabad: ECP.

PILDAT. (August 2018). Assessment of the Quality. Islamabad: Pakistan Institute of Legislative.

PILDAT. (2018). The First 10 General Elections of Pakistan. Islamabad: Pakistan. 